\title{
Importance of physical and biological processes in structuring tropical intertidal populations of Lobophora variegata (Phaeophyceae)
}

\author{
E. D. de Ruyter van Steveninck*, P. Kamermans, A. M. Breeman** \\ Department of Marine Biology, University of Groningen, PO Box 14, 9750 AA-Haren (Gn), The Netherlands
}

\begin{abstract}
On the moderately exposed tropical SW coast of Curaçao (Netherlands Antilles) the encrusting brown alga Lobophora variegata (Lamouroux) Womersley occurs in a narrow belt in the intertidal zone just above the mean sea level. We studied seasonal fluctuations in cover, the influence of grazers, recovery from storm damage and competitive interactions with other algae. Near the upper limit of distribution, fluctuations in cover were observed which paralleled seasonal fluctuations in tidal levels, but lower down, cover remained more or less constant. Grazing did not affect cover or vertical distribution, nor were the $L$. variegata crusts being overgrown by upright algae in the absence of grazers. $L$. variegata recovered quickly from denudation after a storm, and competition with other algae was slight. Dominance of this species over upright algae is attributed to successful adaptation to physical stress (dessication, wave force).
\end{abstract}

\section{INTRODUCTION}

Based on extensive experimental studies in the tropical intertidal zone in Panama (Menge \& Lubchenco 1981, Levings \& Garrity 1984, Lubchenco et al. 1984, Menge et al. 1985, 1986a, b), Menge et al. (1986a) concluded that tropical intertidal communities are structured by the same ecological processes that operate in temperate regions (i.e. predation, competition for space and physical disturbance), although their relative importance varies. Dominance of encrusting algae was primarily ascribed to intense herbivory (Menge \& Lubchenco 1981, Menge et al. 1986a, b), possibly in combination with physical stress (Levings \& Garrity 1984, Lubchenco et al. 1984).

This paper describes a tropical intertidal zone at Curaçao, Netherlands Antilles, where physical stress, rather than grazing, causes dominance of encrusting algae. Here, the brown crustose alga Lobophora variegata (Lamouroux) Womersley forms a distinctive belt in the surf-notch, just above the mean sea level (van den Hoek 1969, van Loenhoud \& van de Sande 1977

- Present address: National Institute of Public Health and Environmental Protection (RIVM), PO Box 1, 3720BA Bilthoven, The Netherlands

- Addressee for correspondence van den Hoek et al. 1978). The factors structuring these intertidal $L$. variegata populations were investigated. Seasonal fluctuations in cover were monitored in relation to seasonal changes in tide levels and experiments were carried out to investigate the possible effect of grazers. Finally, damage to the $L$. variegata population, caused by a storm, provided an opportunity to study recovery and to follow some competitive interactions between $L$. variegata and upright algae, following this natural disturbance.

\section{MATERIAL AND METHODS}

Location and environmental parameters. Intertidal Lobophora variegata populations were studied at Boca St. Michiel (Fig. 1), a moderately exposed location on the leeward southwest coast of Curaçao, Netherlands Antilles (cf. van den Hoek 1969, van den Hoek et al. 1975 for general information on the area). The study site was situated on a vertical limestone cliff wall with a well-developed surf-notch (van den Hoek 1969, Focke 1978), where $L$. variegata formed a ca $15 \mathrm{~cm}$ wide belt just above mean sea level (Fig. 2). It also occurred in scattered patches on the permanently submerged parts of the cliff wall down to the sandy subtidal plateau at ca $0.8 \mathrm{~m}$ depth. 




Fig. 1. Curaçao (Netherlands Antilles), showing the study site, Boca St. Michiel

Mean tidal range at Curaçao is very small, the daily mean being only $29.7 \mathrm{~cm} \pm 10.7$ (SD), and the tides exhibit a periodic change from diurnal to semidiurnal (de Haan \& Zaneveld 1959). Superimposed on daily oscillations is a yearly oscillation of $\mathrm{ca} 15 \mathrm{~cm}$ with lowest tides occurring between January and March, and highest tides between September and November. In addition, significant year-to-year variations in mean tide level may occur (de Haan \& Zaneveld 1959). Tidal fluctuations as measured in Annabaai Harbour, ca $8 \mathrm{~km}$ east of Boca St. Michiel, are presented for the period September 1984 to June 1985 (Fig. 3A), after which date the tide gauge broke. Mean monthly tide levels during this period have been compared with monthly averages over a 6 yr period (de Haan \& Zaneveld 1959) to illustrate seasonal fluctuations (Fig. 3B).

At Curaçao, the trade wind blows for more than $95 \%$ of the time from an easterly direction $\left(90^{\circ}\right)$ with an average speed of $7.1 \mathrm{~m} \mathrm{~s}^{-1}$ (de Palm 1985). However, from 2 to 9 November 1984, a quasi-stationary low pressure area over the eastern Caribbean was responsible for westerly surface winds at Curaçao (mean direction $270^{\circ}$; mean speed $5.1 \mathrm{~m} \mathrm{~s}^{-1}$ ). This 'storm' generated unusually rough seas which caused considerable damage to the normally protected southwest coast. Less severe $\left(2.5 \mathrm{~m} \mathrm{~s}^{-1}\right)$ westerly winds, between 30 October and 5 November 1985, again caused some damage by generating a southwesterly swell.

Observations and experiments. Experiments were carried out at 3 sites differing slightly in height, exposure and topography. At each site permanent quadrats were established in the ca $15 \mathrm{~cm}$ wide belt in which Lobophora variegata was the dominant alga. The sites
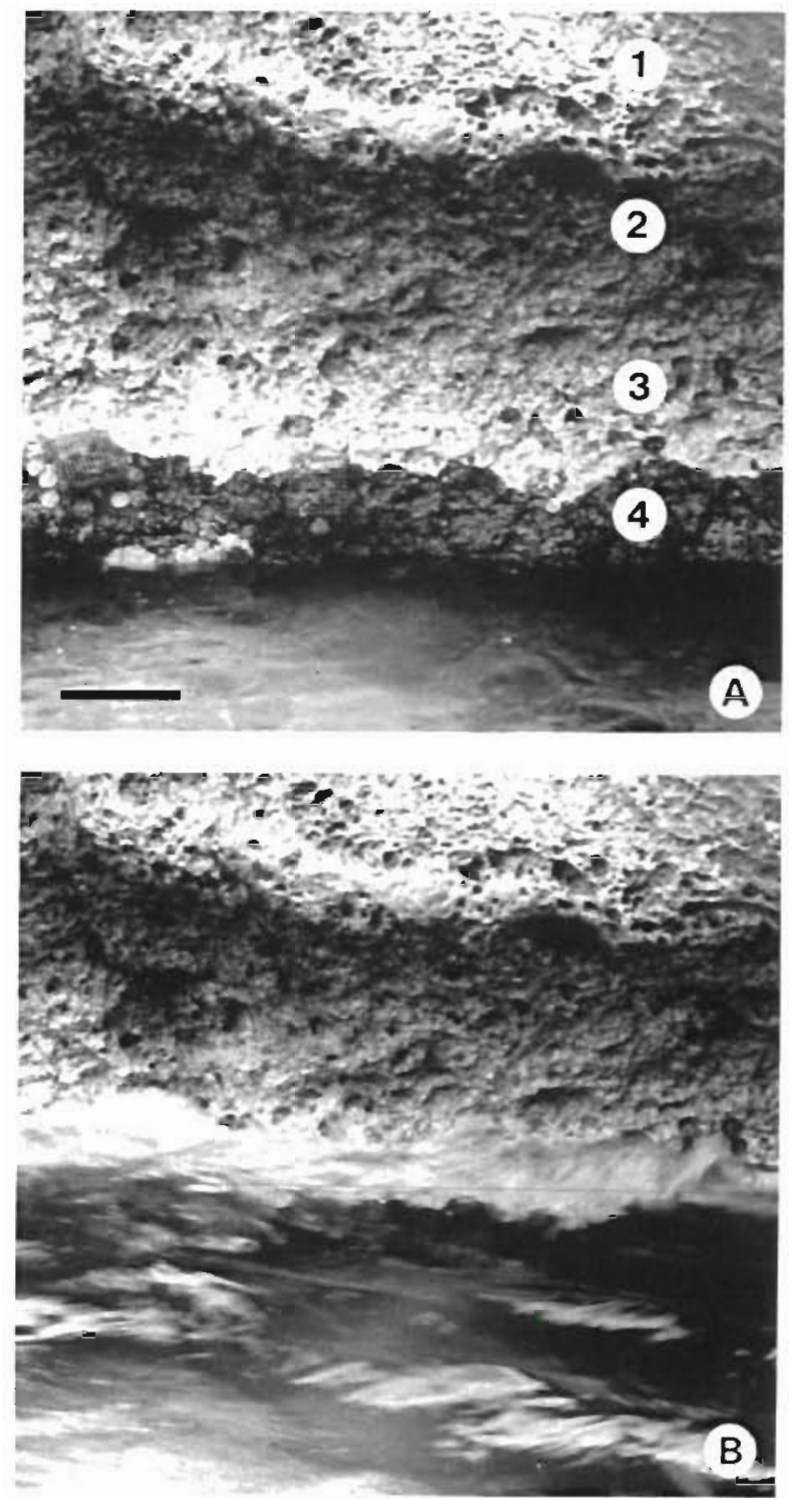

Fig. 2. Surf notch with typical zonation pattern at Boca St. Michiel during (A) wave trough and (B) wave crest. 1: Surf notch roof; 2: bluegreens; 3: crustose corallines; 4 : Lobophora variegata. Bar $=10 \mathrm{~cm}$

were: (1) a vertical cliff without surf-notch; permanent quadrats were established at 'high' levels, ca $+16 \mathrm{~cm}$ CP ('Curaçaos Peil', the tidal datum level for Curaçao; cf. Fig. 3); (2) a surf-notch bottom with angle of inclination of ca $35^{\circ}$; permanent quadrats were established at 'low', 'intermediate' and 'high' levels, between ca +9 and $\mathrm{ca}+17 \mathrm{~cm} \mathrm{CP}$ (Fig. 3); (3) a surf-notch bottom with angle of inclination of ca 35 to $45^{\circ}$; permanent quadrats were established at 'low' levels, ca $+10 \mathrm{~cm}$ CP (Fig. 3). Site 3 was slightly more sheltered than Sites 1 and 2 .

The permanent quadrats measured $5 \times 5 \mathrm{~cm}$, and were marked with steel nails at their corners. The position of the quadrats with respect to tidal height was 
Fig. 3. Tide levels at the entrance of Annabaai Harbour. Levels are referred to 'Curaçaos Peil' (CP) as datum level $(\mathrm{CP}=6.35 \mathrm{~cm}$ below mean sea level; de Haan \& Zaneveld 1959). (A) Daily highest and lowest level during the period 3 Sep 1984 to 21 Jun 1985. (B) (•) Monthly mean tide levels during the period Sep 1984 to Jun 1985, and (o) combined monthly mean tide levels during the period 1950 to 1956 (from de Haan \& Zaneveld 1959); Sites 1 to 3 indicate mean shore levels of the experimental sites
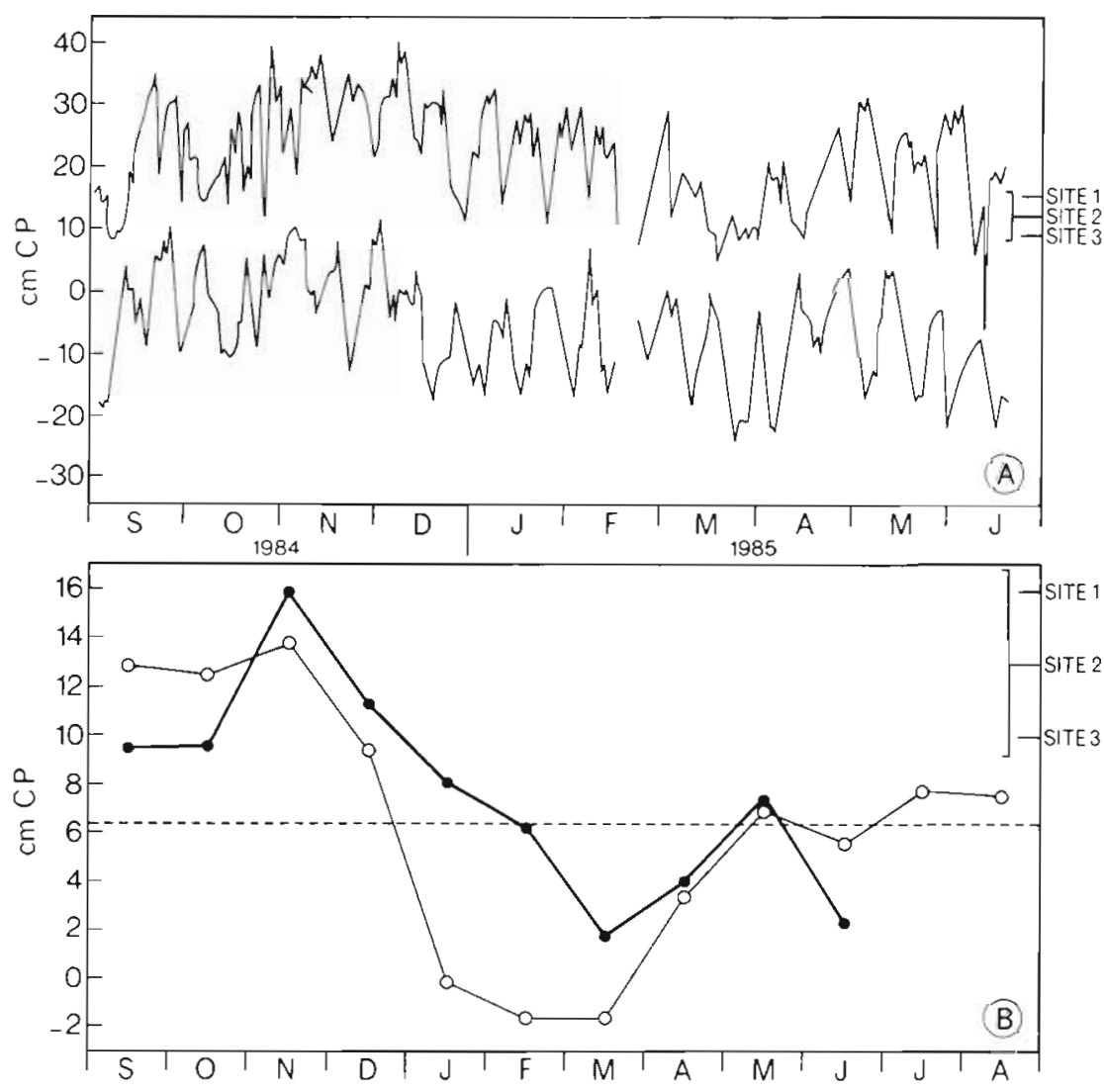

measured using ruler and levelling instrument, and converted to 'Curaçaos Peil', using the tide gauge data.

The position of various components inside the quadrats was determined using a grid with $64(6 \times 6 \mathrm{~mm})$ squares. Each square, in turn, was visualiy divided into $4(3 \times 3 \mathrm{~mm})$ sub-squares. Each time the quadrats were monitored (once every 2 to $4 \mathrm{wk}$ ), the component most abundant in each sub-square was recorded, and thus the percentage cover for each component was determined.

Seasonal fluctuations in cover were recorded over 1 yr in quadrats located at 3 different heights (Table 1). Recovery from storm damage in partially or completely denuded patches in the Lobophora variegata vegetation was studied (Table 1), and interactions with upright algae (e.g. Laurencia papillosa [Forsskål] Grev.) were documented (Table 1). The effect of grazers on the $L$. variegata population was studied at 2 different levels (Table 1 ). Some quadrats were enclosed in a cage (mesh size $6 \times 6 \mathrm{~mm}$ ), some were covered with a roof but had 2 open sides allowing grazers to enter, and others were left undisturbed (Table 1).

Survival of Lobophora variegata below its lower distribution limit in the intertidal zone was investigated by transplanting $L$. variegata to the shallow subtidal plateau at ca $1 \mathrm{~m}$ depth. Substrata with attached $L$. variegata crusts were removed from the intertidal zone and mounted on metal grids using plastic-covered wire. To test for the effect of grazing by fishes and sea urchings, 10 substrata were placed inside cages (mesh

Table 1. Lobophora variegata. Outline of the various observations and experiments at 3 sites situated at different shore levels in the intertidal zone at Boca St. Michiel, Curaçao. $n$ : number of quadrats

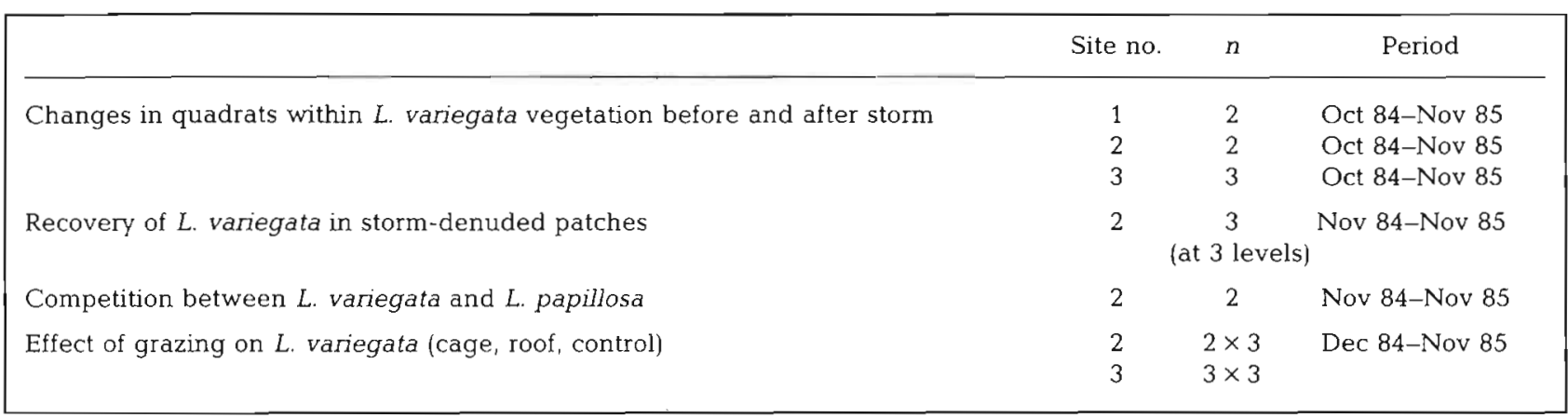



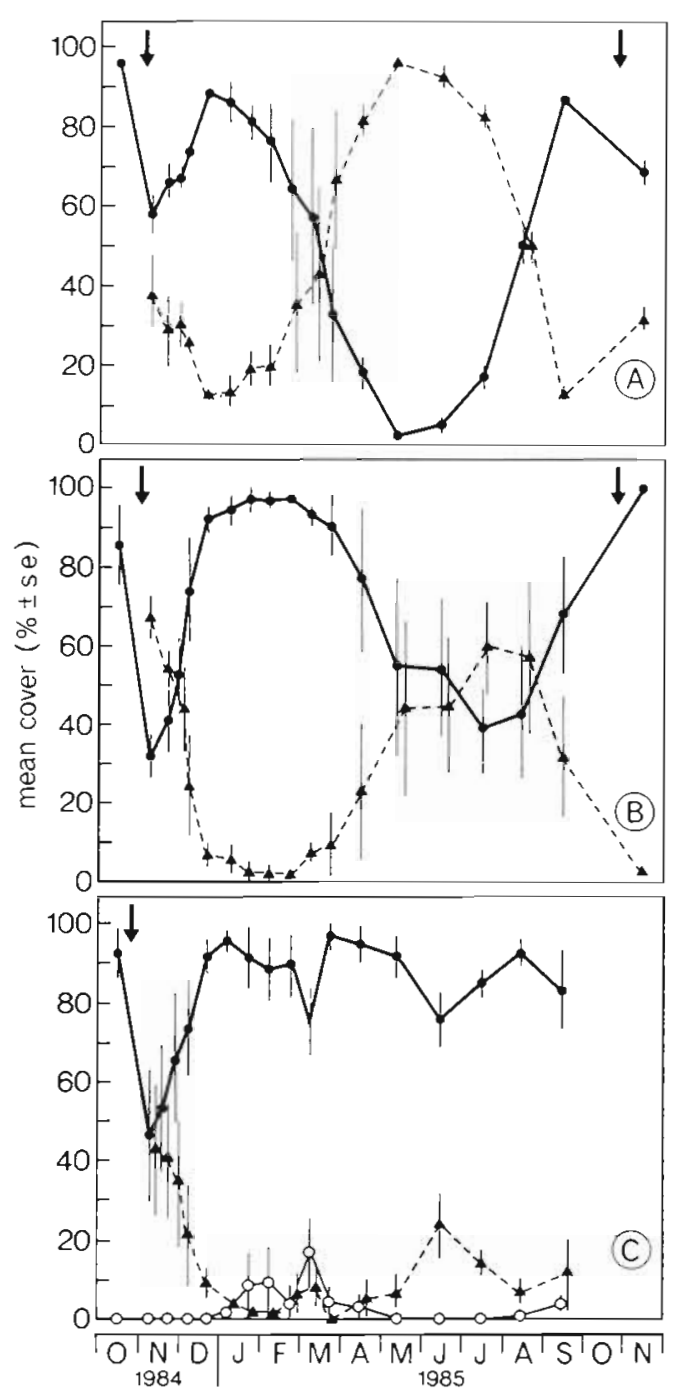

Fig. 4. Lopophora variegata. Fluctuations in cover within quadrats situated at 3 different levels in the intertidal zone. (A) High, Site $1, n=2$; (B) intermediate, Site 2, $n=2$; (C) low, Site $3, n=3 .(\bullet)$ L. variegata; (o) upright algae; (1) crustose corallines; arrows indicate storms

size $12 \times 12 \mathrm{~mm}$ ) and 25 were left unprotected. Cover of L. variegata was estimated visually when the grids were put into place at sunset, over the next $2 \mathrm{~d}$ at sunrise and sunset, and again after 3 mo.

\section{RESULTS}

Seasonal fluctuations in cover of Lobophora variegata at 3 different shore levels are illustrated in Fig. 4. Initial cover in all stets of quadrats was comparable (89 to $96 \%$ ) and the November 1984 storm had a similar effect at each level: an approximately $50 \%$ reduction of $L$. variegata cover. Within $5 \mathrm{wk}$, however, the original degree of cover was re-established, mainly by growth of the remaining $L$. variegata crusts. Mean expansion rate of $L$. variegata in the 7 quadrats was $0.33 \mathrm{~cm}^{2} \mathrm{~d}^{-1}$ \pm 0.14 (SD). This rapid recovery by $L$, variegata was probably facilitated by the relatively high tidal levels (Fig. 3) during this period.

From December 1984 until September 1985, Lobophora variegata cover in the lowest quadrats was fairly constant (Fig. 4C). In contrast, in the higher quadrats (Fig. 4A, B), L. variegata showed a distinct seasonal trend, with cover decreasing after February to reach a minimum between May and July/August. This pattern closely followed seasonal fluctuations in tidal levels (Fig. 3).

Some upright algae were present in the quadrats, but only in the lower ones. For instance, epiphytic plants of Dictyopteris delicatula Lamouroux were found occasionally, but their cover never exceeded $20 \%$. The only

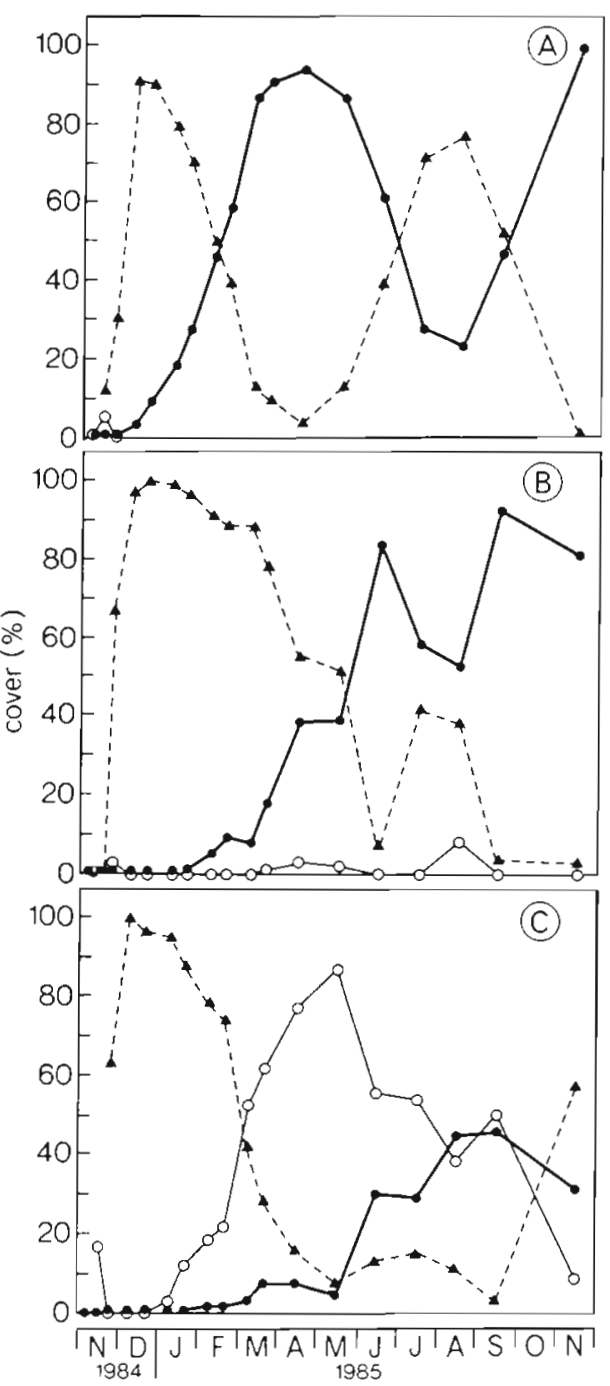

Fig. 5. Lobophora variegata. Colonization of substratum, denuded by storm, in quadrats situated at 3 different levels in the intertidal zone (Site 2). (A) High; (B) intermediate; (C) low

(•) L. variegata; (O) upright algae; (4) crustose corallines 
other important components were crustose corallines, which occupied virtually all substratum unoccupied by L. variegata (Fig. 4).

In the quadrats which had been completely denuded of Lobophora variegata by the November 1984 storm (Fig. 5), the green alga Bryopsis hypnoides Lamouroux was the first colonizer, but this species had disappeared in the next month, when virtually all space was occupied by crustose corallines. From the highest quadrat downward, the rate of recovery of L. variegata decreased (Fig. 5), reflecting the decrease in stormsurviving remnants of the $L$. variegata crusts in the areas surrounding the quadrats, and demonstrating the importance of colonization by vegetative growth as opposed to recruitment of juvenile plants. The effect of seasonal changes in tidal levels was again most pronounced in the higher quadrats (Fig. 5A, B). In the highest quadrat no upright algal species co-occurred with $L$. variegata, but in the lowest quadrat upright algae, especially Dictyopteris delicatula, were sometimes abundant. Fluctuations in cover of upright algae were generally correlated with seasonal fluctuations in tidal level, but the decrease between September and November 1985 may have been caused by rough seas during the first week of November 1985. Again, crustose corallines occupied virtually all space not covered by L. variegata or upright algae (Fig. 5)

Competition with another upright alga was observed in quadrats where, before the storm, Laurencia papillosa had been a co-dominant of Lobophora variegata. Both species, diminished by the stom in November 1984 (Fig. 6), increased in cover to reach maximum values in January (L. papillosa) and March (L. variegata), during which period they were observed to overgrow each other alternately. Extremely low water in March/April 1985 reduced L. papillosa cover

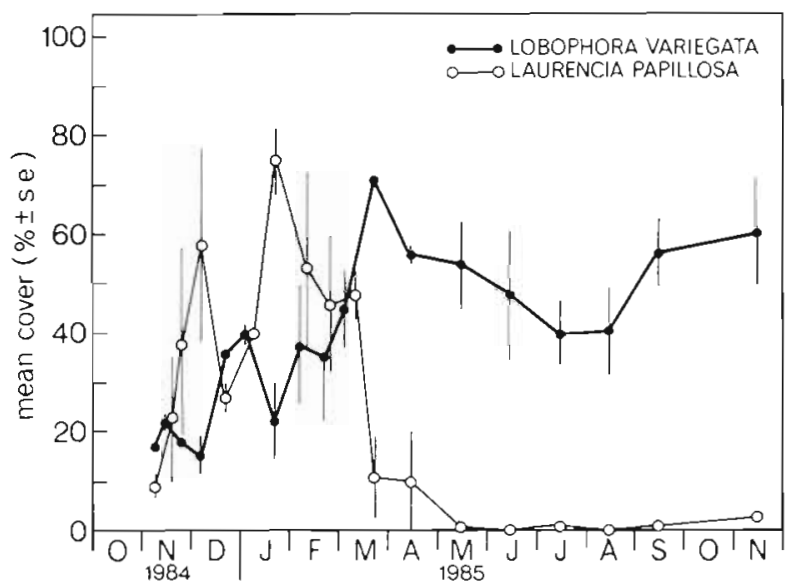

Fig. 6. Lobophora variegata and Laurencia papillosa. Changes in relative abundance in the intertidal zone (intermediate level, Site 2)
Table 2. Herbivorous organisms at the study sites in the intertidal zone at Boca St. Michiel

\begin{tabular}{ll}
\hline Crustacea: & Grapsus grapsus (Linnaeus) \\
Mollusca: & Acmaea sp. \\
& Chiton marmoratus (Gmelin) \\
& Cittarium pica (Linnaeus) \\
& Littorina ziczac (Gmelin) \\
& L. nebulosa (Lamarck) \\
& Nerita peloronta (Linnaeus) \\
& N. tesselata (Gmelin) \\
& Tectarius muricatus (Linnaeus) \\
& 'Keyhole limpet' \\
& Echinometra lacunter (Linnaeus)
\end{tabular}

to almost zero. L. variegata withstood these severe conditions better and, after July, recovered, paralleling increasing tidal levels. Crustose corallines occupied all space not covered by the other 2 species (not shown in Fig. 6).

Several potential grazers were observed in the intertidal zone at Boca St. Michiel (Table 2). However, cage experiments demonstrated that grazing does not affect abundance patterns of Lobophora variegata (Fig. 7). Minimal fluctuations in cover were observed at the lower level, both in caged and non-caged quadrats (Fig. 7D, E, F). However, larger fluctuations, paralleling seasonal fluctuations in tide levels, were observed in the higher quadrats. Again, the caged and non-caged quadrats behaved similarly (Fig. 7A, B, C). The decrease in L. variegata cover observed between Sepiember and November 1985 in the ìowest quadrats may have resulted from rough seas in November 1985 as the lower quadrats (cf. Fig. 5) probably suffered more from the effect of this storm (e.g. through sand scouring) than did the higher ones. Again, abundance of upright algae was highest in the lower quadrats, but they were also present at the higher level within cages, indicating that these plants were affected by herbivory. However, there were no indications that $L$. variegata was overgrown, or otherwise outcompeted by upright algae, when grazers were excluded. Crustose corallines were the only other important occupants of space, covering virtually all substratum not covered by $L$. variegata, and the abundance of these algae was negatively correlated with that of $L$. variegata.

Survival potential of Lobophora variegata below its lower distribution limit in the intertidal zone and the possible effect of grazing is illustrated in Fig. 8. No decrease in $L$. variegata cover was observed inside the cage during the first $2 \mathrm{~d}$. Unprotected $L$. variegata showed some losses during the first day, which points to grazers that are active during daytime. However, after $3 \mathrm{mo}$, there was no longer any difference between grazed and protected substrata, with ca $60 \%$ of the initial cover still being present. This demostrates that 


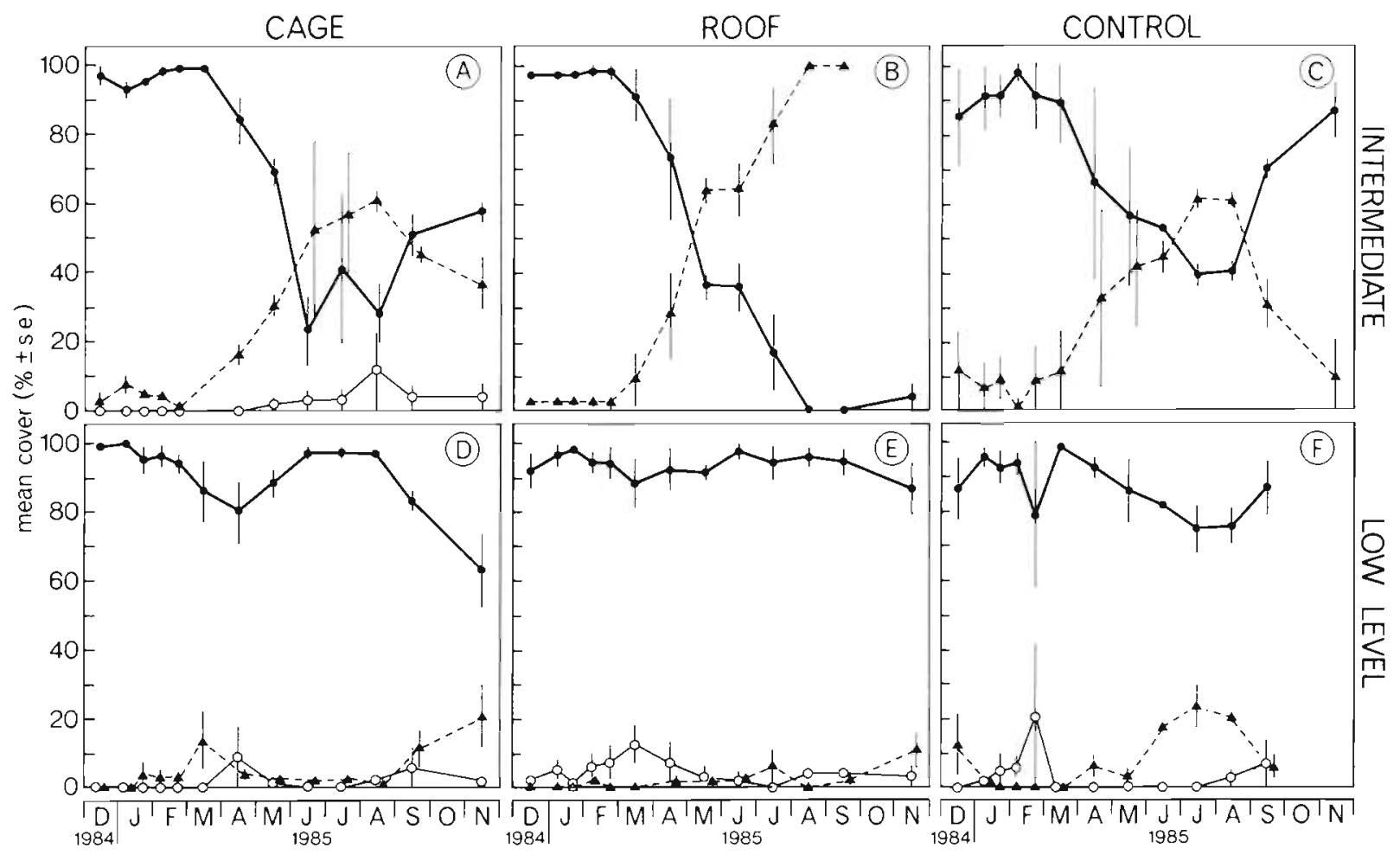

Fig. 7. Lobophora variegata. The effect of grazers in quadrats situated at 2 different levels in the intertidal zone. (A, B, C) Intermediate level (Site 2); (D, E, F) low level (Site 3); (A, D) cage; (B, E) roof $(C, F)$ uncaged control. (•) L. variegata; (O) upright algae; ( $\wedge$ crustose corallines

intertidal $L$, variegata can potentially survive on the shallow subtidal plateau and is not excluded from this zone by grazers.



Fig. 8. Lobophora variegata. Survival potential of intertidal plants when transplanted to the shallow sublittoral plateau (ca $1 \mathrm{~m}$ depth) ( $\bullet$ ) inside and (0) outside cages. d: day; n: night; 3 mo: after 3 mo

\section{DISCUSSION}

In the tropical intertidal zone at Boca St. Michiel, Curaçao, factors other than grazing are responsible for the development of a crustose algal community. This contrasts with findings in Panama, where dominance of encrusting algae was primarily ascribed to intense herbivory (Menge \& Lubchenco 1981, Menge et al. 1986a, b).

The present study demonstrates that, at Curaçao, the abundance of the crustose brown alga Lobophora variegata did not change when protected from grazers. Moreover, the crusts did not develop into blade-like thalli, nor were they overgrown by upright algae. It is likely then that harsh physical conditions, related with desiccation, limit development of upright algae. In general, upright algae were observed only in our lower quadrats. However, their cover was always low and showed seasonal fluctuations paralleling those observed for L. variegata in the highest quadrats, i.e. cover was correlated with seasonal changes in tide levels. These algae are probably more sensitive to physical stress associated with desiccation and, thus, may be incapable of successfully outcompeting $L$. variegata crusts. In fact, mortality of upright algae in the intertidal zone was repeatedly observed after a period with exceptionally low water levels. These conditions also affected $L$. variegata, but to a lesser extent. The rapid recovery of $L$. variegata following the November 
1984 storm also confirms competitive superiority of $L$. variegata over other algal species under stressful conditions

The studied tropical intertidal community at Curaçao clearly differs from that on the Pacific coast of Panama (Menge \& Lubchenco 1981, Levings \& Garrity 1984 , Lubchenco et al. 1984, Menge et al. 1986a). At the latter coast, with a tidal range of $6 \mathrm{~m}$ instead of $0.3 \mathrm{~m}$, and the substratum consisting of basalt instead of limestone, both physical and biological factors are clearly different from those at Curaçao. In Panama, fish grazing seems to be important, whereas fish are virtually absent from the intertidal zone at Curaçao. Moreover, basalt dries more rapidly than limestone which, even in temperate areas, may greatly affect algal growth and upper zonal limits (den Hartog 1959, 1972). In spite of these differences, both communities were dominated by crustose algae and lacked abundant upright algae. Dominance of crustose algae is generally attributed to intense herbivory (Lubchenco \& Cubit 1980, Slocum 1980, Dethier 1981, Menge \& Lubchenco 1981, Bertness et al. 1983, Littler et al. 1983a, b, Menge et al. 1986a, b), by which grazers are thought to remove epiphytic algae, thus favouring the development of grazer-resistant algal crusts. However, Padilla (1985) demonstrated low resistance to limpet grazing for a calcified crustose alga and concluded that thallus form alone is a poor predictor of structural resistance to molluscan feeding. In addition, Norton et al. (1982) and Littler \& Littler (1983) have suggested that crusts are less susceptible to physical stress (desiccation, waveshearing) than are erect thalli, and Underwood (1980, 1985), Gaines \& Lubchenco (1982), Levings \& Garrity (1984) and Lubchenco et al. (1984) attributed the development of a crustose algal community to a combination of herbivory and physical stress.

At Curaçao, Lobophora vanegata was present all year round in a narrow intertidal belt $(\mathrm{ca} 15 \mathrm{~cm})$. As the mean tidal range at Curaçao is only about $30 \mathrm{~cm}$ (de Haan \& Zaneveld 1959) wave force has been considered to be the main cause of species zonation (van Loenhoud \& van de Sande 1977). Yet, the present study demonstrates that an even smaller seasonal oscillation in water level of $\mathrm{ca} 15 \mathrm{~cm}$ is responsible for distinct seasonal variations in $L$. variegata cover near its upper limit of distribution. In contrast, at lower levels, $L$. variegata cover remained more constant, but increasing abundance of upright algae suggests that competition may become more important. $L$. variegata is absent from the shallow sublittoral plateau, possibly because of high sediment cover or increased competition with upright algae. Grazers do not seem to be responsible, probably because strong surge limits effective grazing by herbivorous fishes so close to the shore, as susceptibility of intertidal $L$. variegata plants to grazing has been observed at greater depths $(12$ and $30 \mathrm{~m}$ : de Ruyter van Steveninck et al. unpubl.).

In the tropical intertidal zone at Curaçao, physical stress is clearly the main factor responsible for the dominance of a crustose algal community. Thus, it seems that the factors structuring tropical intertidal communities may vary from one coast to another, depending on environmental parameters, and that grazing is not always the main force responsible for the dominance of encrusting algae.

Acknowledgements. We thank the director and staff of the Caribbean Marine Biological Institute (CARMABI) for working facilities. Global radiation and storm data were kindly made available by A. J. Dania (Meteorological Service Curaçao). Tidal gauge data were provided by the Curaçao Port Service (Messrs. Hendriks, Martina and Oudenolder). Dolf Debrot identified the Mollusca and Prof. Dr C. van den Hoek and Dr I. Novaczek critically read the manuscript; this is gratefully acknowledged. The manuscript has benefitted from the comments of 2 anonymous referees. The first author was supported by a grant from the Netherlands Foundation for the Advancement of Tropical Research (WOTRO) W84-201. The second author received support from the funds: 'Fonds Dr C L. van Steeden', 'Fonds Dr Catharina van Tussenbroek' and 'Groninger Universiteit Fonds'.

\section{LITERATURE CITED}

Bertness, M. D., Yund, P. O., Brown, A. F. (1983). Snail grazing and the abundance of algal crusts on a sheltered New England rocky Beach. J. exp. mar. Biol. Ecol. 71: 147-164

Dethier M. N. (1981). Heteromorphic algal life histories: the seasonal pattern and response to herbivory of the brown crust, Ralfsia californica. Oecologia (Berl.) 49: 333-339

Focke, J. W. (1978). Limestone cliff morphology and organism distribution on Curaçao (Netherlands Antilles). Leidse Geol. Med. 51: 131-150

Gaines, S. D., Lubchenco, J. (1982). A unified approach to marine plant-herbivore interactions. II. Biogeography. Ann. Rev. Ecol. Syst. 13: 111-138

Haan, D. de, Zaneveld, J. S. (1959). Some notes on tides in Annabaai harbour, Curaçao, Netherlands Antilles. Bull. mar. Sci. Gulf Caribb. 9: 224-236

Hartog, C. den (1959). The ephilithic algal communities occurring along the coast of the Netherlands. North-Holland Publishing Co., Amsterdam

Hartog, C. den (1972). Substratum. Multicellular plants. In: Kinne, O. (ed.) Marine ecology, Vol. 1, Environmental factors, Part 3. Wiley-Interscience, London, p. 1277-1289

Hoek, C. van den (1969). Algal vegetation-types along the open coasts of Curaçao, Netherlands Antilles. Proc. K. Ned. Akad. Wet. Ser. C 72: 537-577

Hoek, C. van den, Breeman, A. M., Bak, R. P. M., Buurt, G. van (1978). The distribution of algae, corals and gorgonians in relation to depth, light attenuation, water movement and grazing pressure in the fringing coral reef of Curaçao, Netherlands Antilles. Aquat. Bot. 5: 1-46

Hoek, C. van den, Cortel-Breeman, A. M., Wanders, J. B. W. (1975). Algal zonation in the fringing coral reef of Curaçao, Netherlands Antilles, in relation to zonation of corals and gorgonians. Aquat. Bot. 1: 269-308

Levings, S. C., Garrity, S. D. (1984). Grazing patterns in 
Siphonaria gigas (Mollusca, Pulmonata) on the rocky Pacific coast of Panama. Oecologia (Berl.) 64: 152-159

Littler, M. M., Littler, D. S. (1983). Heteromorphic life-history strategies in the brown alga Scytosiphon lomentaria (Lyngb.) Link. J. Phycol. 19: 425-431

Littler, M. M., Littler, D. S., Taylor, P. R. (1983a). Evolutionary strategies in a tropical barrier reef system: functional-form groups of marine macroalgae. J. Phycol. 19: 229-237

Littler, M. M., Taylor, P. R., Littler, D. S. (1983b). Algal resistance to herbivory on a Caribbean barrier reef. Coral Reefs 2: $111-118$

Loenhoud, P. J. van, Sande, J. C. P. M. van de (1977). Rocky shore zonation in Aruba and Curaçao (Netherlands Antilles), with the introduction of a new general scheme of zonation. Proc. K. Ned. Akad. Wet. Ser. C 80: 437-474

Lubchenco, J., Cubit, J. (1980). Heteromorphic life histories of certain marine algae as adaptations to variations in herbivory. Ecology 61: 676-687

Lubchenco, J., Menge, B. A., Garrity, S. D., Lubchenco, P. J., Ashkenas, L. R., Gaines, S. D., Emlet, R, Lucas, J., Strauss, S. (1984). Structure, persistence, and role of consumers in a tropical rocky intertidal community (Taboguilla Island, Bay of Panama). J. exp. mar. Biol. Ecol. 78: 23-73

Menge, B. A., Lubchenco, J. (1981). Community organization in temperate and tropical rocky intertidal habitats: prey refuges in relation to consumer pressure gradients. Ecol. Monogr. 51: 429-450

Menge, B. A., Lubchenco, J., Ashkenas, L. R. (1985). Diversity, heterogeneity and consumer pressure in a tropical rocky intertidal community. Oecologia (Berl.) 65: 394-405

Menge, B. A., Lubchenco, J., Ashkenas, L. R., Ramsey, F. (1986a). Experimental separation of effects of consumers on sessile prey on a rocky shore in the Bay of Panama: direct and indirect consequences of food web complexity. J. exp. mar. Biol. Ecol. 100: 225-269

Menge, B. A., Lubchenco, J., Gaines, S. D., Ashkenas, L. R. (1986b). A test of the Menge-Sutherland model of community organization in a tropical rocky intertidal food web. Oecologia (Berl.) 71: 75-89

Norton, T. A., Mathieson, A. C., Neushul, M. (1982). A review of some aspects of form and function in seaweeds. Botanica mar. 25: 501-510

Padilla, D. K. (1985). Structural resistance of algae to herbivores. A biomechanical approach. Mar. Biol. 90: 103-109

Palm, J. Ph. de (ed.) (1985). Encyclopedie van de Nederlandse Antillen. De Walburg Pers, Zutphen

Slocum, C. J. (1980). Differential susceptibility to grazers in two phases of an intertidal alga: advantages of heteromorphic generations. J. exp. mar. Biol. Ecol. 46: 99-110

Underwood, A. J. (1980). The effects of grazing by gastropods and physical factors on the upper limits of distribution of intertidal macroalgae. Oecologia (Berl.) 46: 201-213

Underwood, A. J. (1985). Physical factors and biological interactions: the necessity and nature of ecological experiments. In: Moore, P. G., Seed, R. (eds.) The ecology of rocky coasts. Holder and Stoughton, London, p. 372-390

This article was submitted to the editor; it was accepted for printing on February 15, 1988 